\title{
Символы Республики Казахстан: исторический путь и современные реалии
}

\begin{abstract}
Аннотаиия. Предметом исследования данной работы является история символов Республики Казахстан. Ввиду того что гералъдика не была свойственна кочевым народам, первые символь на территорию современного Казахстана принесла Российская империя. Дальнейшее развитие геральдики Казахстана, входившего в состав Российской империи и СССР, проходило синхронно с развитием геральдики в этих странах. Свои первые самостоятельные символь Республика Казахстан приобрела после распада СССР в 1991 г. Однако, в отличие от других стран постсоветского пространства, данные символы были структурированы, выделенъ в отдельнъии конституиионный закон и описаны стандартом. Так был решен вопрос с неоднозначностъю трактовок символов, а флаг и герб стали сочетаться в иветах, что позволило рассматривать их как единую художественную композичию. В работе не только показаны сильнье сторонъ герба и флага, но и разобрань их основнье неточности, которые имеют догматический характер. В исследовании использовался исторический подход, показывающий геополитические явления и предпосълки при создании герба Республики Казахстан. Историко-сравнительный метод - наряду с историко-генетическим методом - показал возможную преемственность от старых земельнъх гербов к современному гербу государства. Все вышеуказаннъе методъ позволили определить основнъе реперные точки исследования. Основной вывод статьи сводится к констатачии, ито герб Казахстана хотя и содержит в себе ряд догматических ошибок, однако сделан со скрупулезностью и художественным вкусом. Он символизирует мир, благосостояние и процветание народа. Символика герба показывает интеграционный вектор развития государства. Герб и флаг Казахстана по своей структуре и символизму близки к символам Республики Беларусь - прослеживается их единая преемственность из символов советской эпохи. Геральдка Республики Казахстан имеет тендениию к развитию в рамках Евразийского Союза, и именно казахстанский опыт стандартизачии гералъдки может бытъ использован как эталон для государств этого интеграчионного объединения.
\end{abstract}

Ключевые слова: геральдика, герб, история Казахстана, ошибки в гербе, флаг, территория Казахстана, символь Казахстана, политическое устройство, прогностические аспекты геральдики, стандартизачия символов.

Abstract. The object of this article's research is the history of the symbols of the Republic of Kazakhstan. In view of the fact that heraldry was not inherent to the culture of nomadic people, the first symbols were brought into the territory of modern Kazakhstan by the Russian Empire. The further development of heraldry in Kazakhstan, which was part of the Russian Empire and later of the USSR, occurred synchronically with the development of heraldry in these states. The Republic of Kazakhstan got its first independent symbols after the collapse of the USSR in 1991. However, unlike other countries of the former Soviet Union, these symbols were formalised, registered in a separate law, and described by a standard. Thus, the issue of the ambiguous symbol interpretations was resolved and the nation's flag and coat of arms were made to correspond in colour, thereby allowing them to be seen as a unified artistic composition. This article demonstrates not only the strong sides in the composition of the Kazakhstan coat of arms and flag, but also examines their chief inaccuracies, which are of a dogmatic nature. This research utilised the historical approach which illuminated the geopolitical phenomena and prerequisites in creating the coat of arms of the Republic of Kazakhstan. The historical and comparative method - along with the historical-genetic method - exposed the possible continuity from old territorial coats of arms to the state's modern coat of arms. All of the above listed methods have allowed to identify the main reference points of this research. The main conclusion of the article amounts to the observation that the Kazakhstan coat of arms, despite having a number of dogmatic mistakes, nonetheless was made with scrupulousness and artistic taste. It symbolises peace, welfare, and prosperity of the people. The symbolics of the coat of arms show an integrative vector in the state's development. The coat of arms and the flag of Kazakhstan in their structure and symbolism are similar to the symbols of the Republic of Belarus - the author notes their same continuity from the symbols of the Soviet era. The heraldry of the Republic of Kazakhstan leans toward its development within the framework of the Euroasian Union, and the Kazakhstan experience of heraldic standardisation can be used as a model for other states in this integrative association.

Key words: heraldry, coat of arms, history of Kazakhstan, emblem mistakes, flag, territory of Kazakhstan, symbols of Kazakhstan, political system, heraldic prognostic aspects, symbol standardisation. 


\section{Вспомогательные исторические дисциплины}

Казахстан имеет уникальное геополитическое положение. Через земли современного Казахстана проходили пути переселения многих народов, эти территории обогащались за счет торговой артерии Азии - Великого шелкового пути. Казахстанские степи и пустыни неоднократно становились центром огромных государств, которые затем распадались на мелкие племенные союзы. Грамотные предводители ханств перед лицом угрозы с восточной мудростью находили сильных союзников, тем самым спасая народ и самобытную культуру, а также расширяя границы собственного государства. Так, в V в. на территории современного Казахстана возникает племенной союз - Тюркский каганат. После распада каганата его осколки поглощаются Монгольской империей. Территория современного Казахстана попадает под протекторат Золотой Орды. Держава Чингисхана и империя Тимура оставляют яркий след в виде новых городов и царств. Так, при распаде Золотой Орды в XV в. впервые появляется самостоятельное Казахское ханство. Однако существует оно недолго, внутренние противоречия и постоянные внешние угрозы приводят ханство к гражданской войне с последующим разделом на более мелкие жузы. Пытаясь сохранить собственный народ и культуру, правители казахских жузов начиная с конца XVII - начала XVIII вв. принимают решение самостоятельно интегрироваться в Российскую империю, чтобы тем самым защитить свои земли от притеснений со стороны Джунгарского и Бухарского ханств. Необходимо отметить, что казахские ханы начали строить добрые отношения с русскими царями еще со времен Ивана Грозного. Поэтому мудро реализованная внешняя политика, подкрепленная торговыми связями, привела Казахстан в состав Российской империи.
Были ли гербы у Казахского ханства? Можно сказать однозначно, что нет. Геральдика была чужда кочевым народам, но флаги и символы - например, тамга - присутствовали в культуре казахского народа. Наряду с собственными символами культура казахов обогащалась заимствованными символами Золотой Орды и соседних ханств. Так, тамга является родовым знаком-оберегом. Но это не стационарный знак, он видоизменяется от предка к потомку, причем часто без каких-либо правил. Тамга как родовой знак часто встречается в культуре тюркоязычных народов - таких, как карачаевцы, балкарцы, черкесы, татары, башкиры, узбеки, казахи, киргизы, ногайцы. Но она характерна и для других народов - например, марийцев, осетин, монголов и т. д. [1, 5-15]. В современном мире тамгу можно назвать эмблемой, но не гербом. Классические гербы на землях современного Казахстана и примыкающих к нему стран появились только после их вхождения в состав Российской империи. Вошедшие земли Средней Азии включали в себя территории современных Узбекистана, Туркменистана, Таджикистана, Киргизии и Казахстана и назывались в составе Российской империи собирательным термином «Туркестан». Современный Казахстан был сформирован из следующих регионов Российской империи: Уральская область, Тургайская область, Акмолинская область, Семипалатинская область, Семиречинская область, Сыр-Дарьинская область, части Закаспийской области и Астраханской губернии. Гербы данных регионов и герб Туркестанского генерал-губернаторства представлены в таблице 1 (в статье все гербы изображены в черно-белом формате без шраффировки, но с блазоном).

\begin{tabular}{|l|l|}
\hline \multicolumn{2}{|c|}{ Гербы регионов Российской империи, из территорий которых был сформирован Казахстан } \\
\hline
\end{tabular}




\section{Исторический журнал: научные исследования № 5 (29) • 2015}

DOI: 10.7256/2222-1972.2015.5.17290

Продолжение таблииы 1

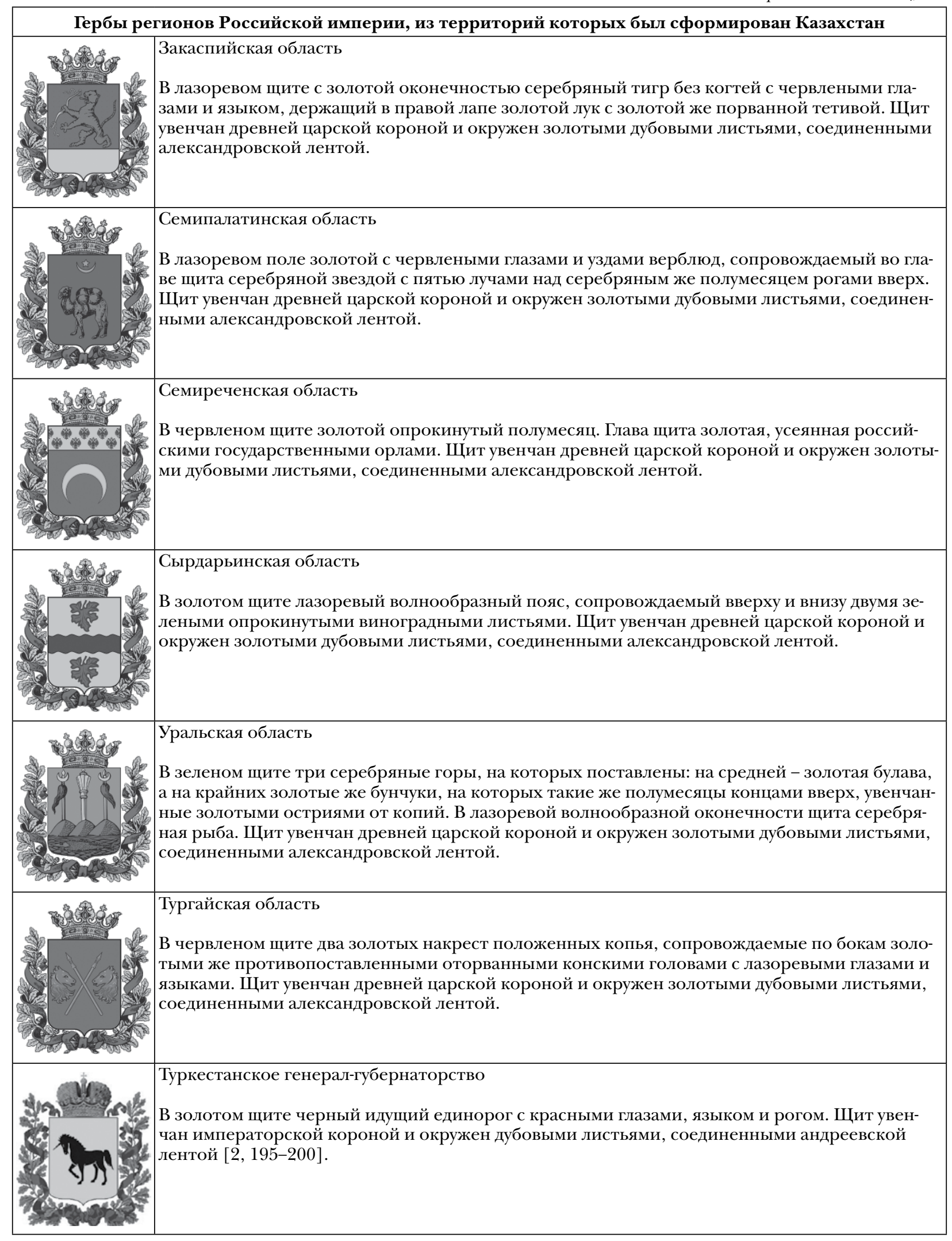




\section{Вспомогательные исторические дисциплины}

DOI: $10.7256 / 2222-1972.2015 .5 .17290$

Как видно, с вхождением в состав Российской империи земельная геральдика казахских территорий приобрела яркие, выразительные и узнаваемые черты. Дальнейшее развитие геральдики на данной земле проходило все те же этапы, как и геральдика России. Герб туркестанских земель на законных правах вошел в Большой герб Российской империи. Данный герб полностью совпадает с гербом Туркестанского генерал-губернаторства.

После революции 1917 г. классическая геральдика на территории Российской империи была предана забвению. В период с 1917 по 1920 гг. на землях современного Казахстана появляются Алашская и Туркестанская автономии. Однако, согласно кочевым традициям, данные государственные структуры остаются безликими и не имеют утвержденных гербов или флагов. В период с 1920 по 1925 гг. на месте предыдущих автономий возникает Киргизская АССР, а впоследствии - Казакская АССР (1925-1936 гг.). В этот период формируется традиционная символика республик, характерная для раннего советского периода (см. рис. 1).

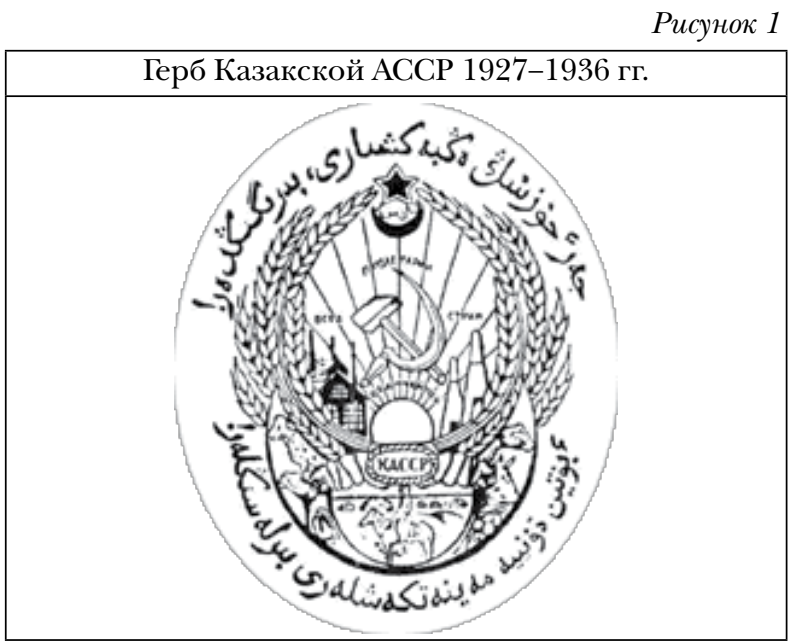

При выборе герба проводился конкурс, в котором победил проект художника Александра Сергеевича Иванова. То есть первый советский вариант герба Казакской ACСР с надписями на русском, казахском и каракалпакском языках в арабской графике (сверху надпись на казахском языке, в центре герба на русском, а внизу на каракалпакском) появился только в 1927 г. Можно предположить, что третья надпись была сделана вследствие того, что в 1924-1930 гг. Кара-Калпакская автономная область входила в состав Казакской АССР [3, 56]. В 1937 г. Казахская ССР получает стандартный герб союзной республики.
Надо отметить, что ее герб был одним из самых ординарных и не отличался художественными изысками, как, например, гербы Грузинской или Армянской ССР [4, 80-90]. Этот герб претерпел два этапа изменений. Первый этап: в 1939 г. изменяются все надписи на казахском языке в латинизированном алфавите на надписи в алфавите на основе русской азбуки. Второй этап: в 1978 г. происходит изменение наложения серпа. Серп стал вновь изображаться наложенным на молот. Также уменьшаются интенсивность красного фона и количество лучей солнца. Таким образом, можно видеть, что серьезных изменений герб не претерпел, были внесены исключительно художественные и алфавитные правки (см. рис. 2).

Рисунок 2

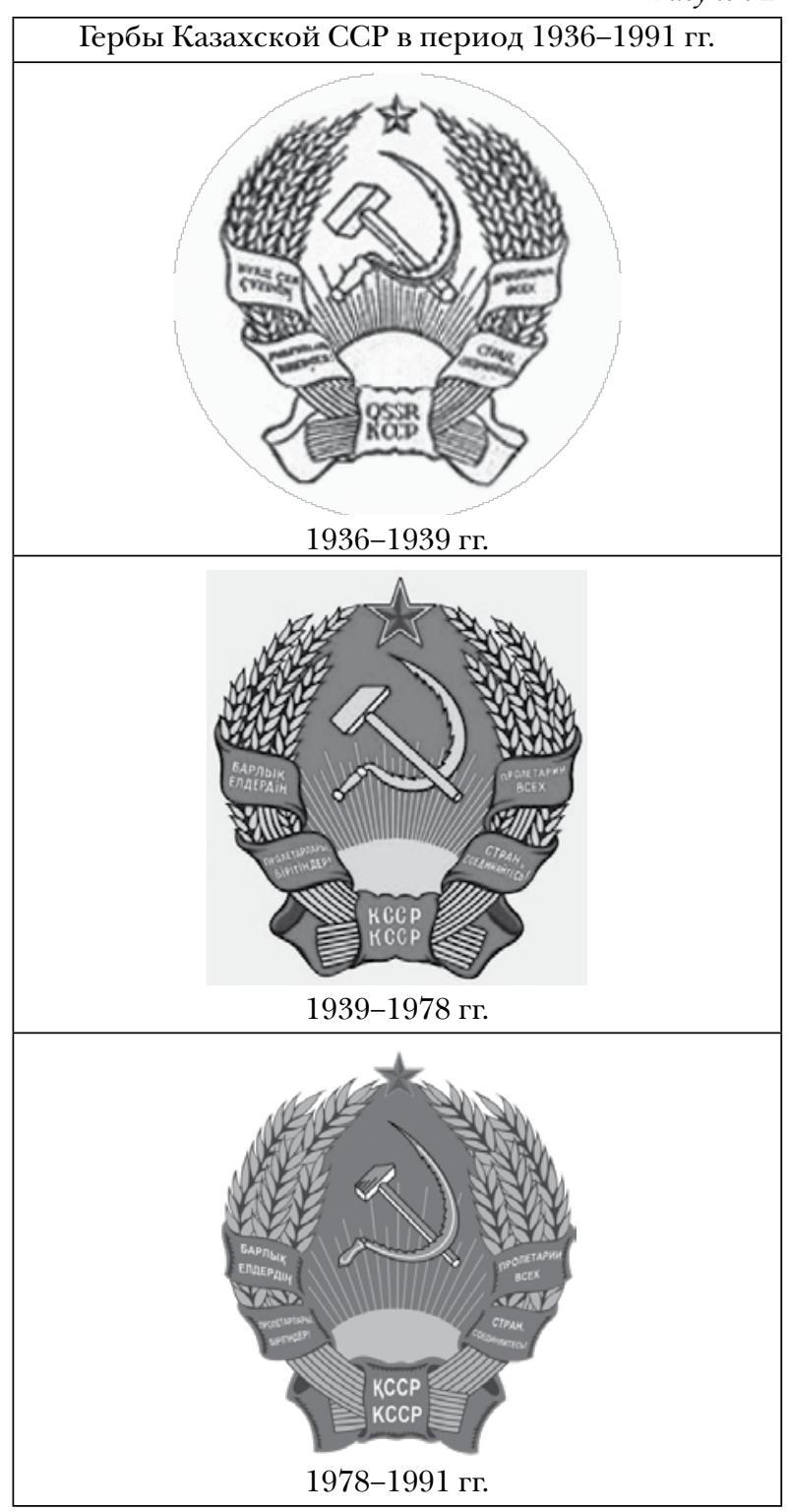




\section{Исторический журнал: научные исследования № 5 (29) • 2015}

DOI: $10.7256 / 2222-1972.2015 .5 .17290$

В статье 121 Конституции Казахской ССР 1936 г. дано следующее описание герба: «Государственный герб Казахской Советской Социалистической Республики состоит из изображения золотых серпа и молота, помещенных крест-накрест, рукоятками книзу, на красном фоне в лучах солнца и в обрамлении колосьев, с надписью на казахском и русском языках: "Пролетарии всех стран, соединяйтесь!" Наверху герба имеется пятиконечная звезда, а в нижней его части - надпись "Казахская С. С. Р." на казахском и русском языках» [5, 99-101].

Так же, как и герб Казахской ССР, флаг республики претерпел два изменения, связанных с заменой алфавита и последующей унификацией символов республик Советского Союза (см. рис. 3).

Рисунок 3

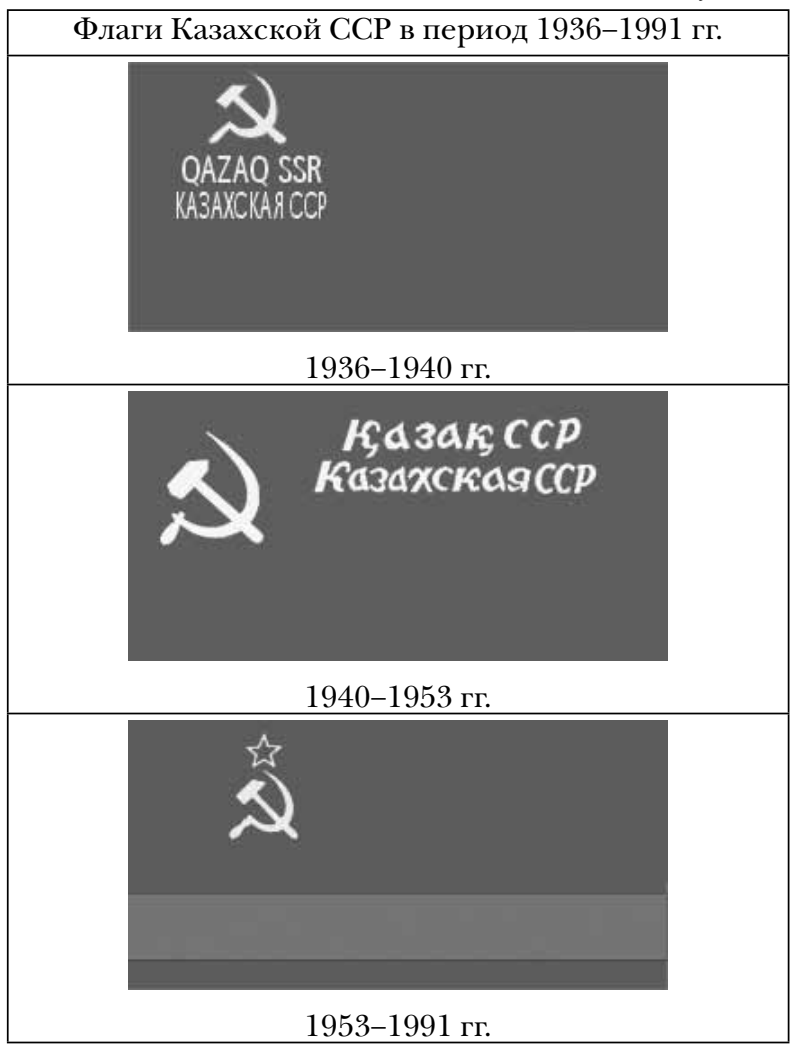

В Конституции Казахской ССР 1978 г. дано следующее описание флага республики: «Государственный флаг Казахской Советской Социалистической Республики представляет собой полотнище, состоящее из трех горизонтально расположенных цветных полос: верхней красного цвета, составляющей две трети ширины флага, средней лазуревого цвета, составляющей две девятых ширины флага, нижней красного цвета, составляющей одну девятую ширины фла- га. На верхней красной части полотнища флага на расстоянии одной четверти длины флага от древка изображены золотые серп и молот и над ними красная пятиконечная звезда, обрамленная золотой каймой. Отношение ширины флага к его длине 1:2» [5, 99-101].

После распада СССР и провозглашения независимости Казахстана остро встал вопрос о символах нового государства. По сути, геральдика Казахстана берет свое начало именно в 1991 г. Несмотря на отсутствие у государства геральдического опыта ввиду особенности менталитета и образа жизни народа, можно смело утверждать, что символы герба и флага выбраны очень удачно. Прослеживается некая преемственность основных символов герба Казахстана от герба Туркестанского генерал-губернаторства. Герб Казахстана не является традиционным, в нем объединились как кочевой эпос народа, так и советская геральдическая школа. Верно подобраны цвета герба и флага, несущие смысл стабильного развития и духовности, богатства народа и мира. Необходимо отметить, что флаг и герб Казахстана, принятые в 1991 г., никогда не поднимались против России - в отличие от флагов Алашской и Туркестанской автономий в годы Гражданской войны (см. рис. 4), эти символы не использовались коллаборационистами [6, 36-58] во время Великой Отечественной войны.

Флаг и герб Казахстана не опорочены борьбой с Россией, как флаги и гербы некоторых постсоветских стран, чья современная политика строится на отрицании общей истории. Герб и флаг Республики Казахстан выбирались после объявленного конкурса. Они были определены из 245 вариантов гербов и 453 вариантов флагов. Такого количества работ не было ни в одном государстве постсоветского пространства. Авторами герба республики являются заслуженный архитектор Казахстана, лауреат Государственной премии Республики Казахстан Шота-Аман Идрисович Уалиханов и заслуженный архитектор Узбекистана Жандарбек Малибекович Малибеков. Автором флага республики стал заслуженный деятель искусств Республики Казахстан художник Шакен Онласынович Ниязбеков.

Герб Республики Казахстан, претерпев с 1991 г. незначительные изменения по сравнению с первоначальным эскизом, был утвержден указом президента Республики Казахстан № 2797 « государственных символах Республики Казахстан» от 24 января 1996 г. [7, 178]. Можно предположить, что в период с 1991 по 1996 гг. 
Вспомогательные исторические дисциплины

DOI: $10.7256 / 2222-1972.2015 .5 .17290$

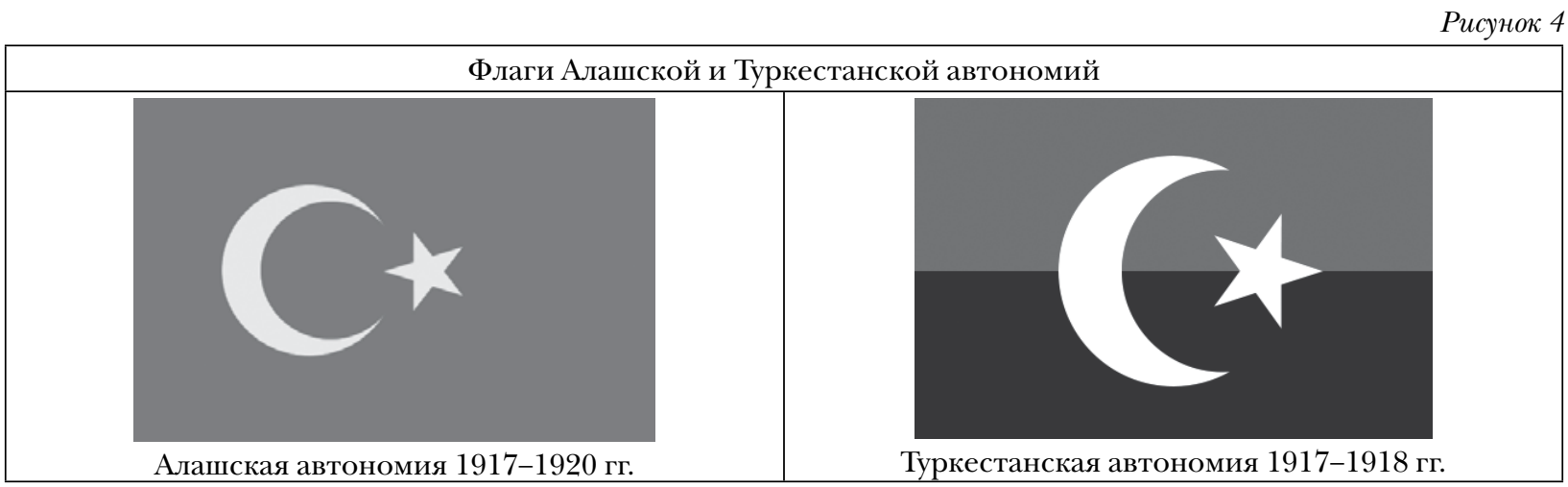

Рисунок 5

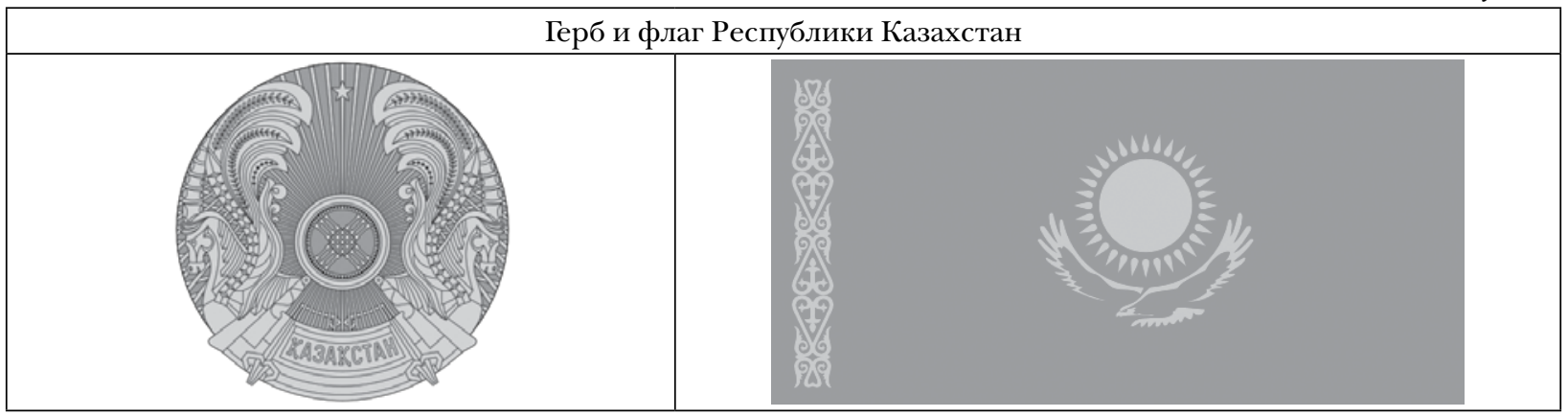

герб использовался руководством Казахстана в «тестовом» режиме, чтобы понять, насколько новый символ республики будет принят народом. Описание герба было изложено в главе III статьи 7 названного указа: «Государственный герб Республики Казахстан представляет собой изображение шанырака (верхняя сводчатая часть юрты) на голубом фоне, от которого во все стороны в виде солнечных лучей расходятся уыки (опоры) в обрамлении крыльев мифических коней. В нижней части герба - надпись "Казакстан”. В цветном изображении государственный герб Республики Казахстан двух цветов: золота и сине-голубого».

В том же указе № 2797 в главе II статьи 4 следующим образом описан флаг республики: «Государственный флаг Республики Казахстан представляет собой прямоугольное полотнище голубого цвета с изображением в его центре солнца с лучами, под которым - парящий орел. У древка - вертикальная полоса с национальным орнаментом. Изображение солнца, лучей, орла и орнамента - цвета золота. Отношение ширины флага к его длине - 1:2».

Герб, флаг и гимн были описаны в конституционном законе Республики Казахстан «О государственных символах Республики Казахстан» № 258 от 4 июня 2007 г. в главе 1 статьи 1 сле- дующим образом (см. рис. 5): «Государственный герб Республики Казахстан имеет форму круга и представляет собой изображение шанырака (верхняя сводчатая часть юрты) на голубом фоне, от которого во все стороны в виде солнечных лучей расходятся уыки (опоры). Справа и слева от шанырака расположены изображения мифических крылатых коней. В верхней части расположена объемная пятиконечная звезда, а в нижней части - надпись “Қазақстан”. Изображение звезды, шанырака, уыков, мифических крылатых коней, а также надписи "Қазақстан” цвета золота.

Государственный флаг Республики Казахстан представляет собой прямоугольное полотнище голубого цвета с изображением в центре солнца с лучами, под которым - парящий орел. У древка - национальный орнамент в виде вертикальной полосы. Изображение солнца, его лучей, орла и национального орнамента - цвета золота. Соотношение ширины флага к его длине - 1:2» [8].

После окончательного закрепления описания герба и флага были определены правила использования, размещения и исполнения символов государства в постановлении правительства Республики Казахстан № 873 от 2 октября 2007 г. Однако этим законотворческая деятельность не 


\section{Исторический журнал: научные исследования № 5 (29) • 2015}

DOI: $10.7256 / 2222-1972.2015 .5 .17290$

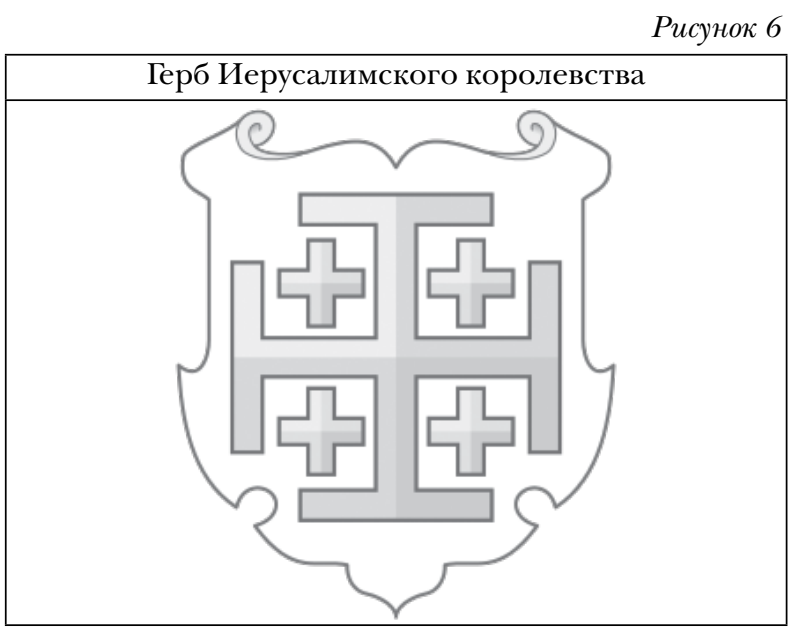

ограничилась. Стоит поставить в пример многим государствам то, с какой скрупулезностью были разработаны государственные стандарты Республики Казахстан (СТ РК 989-2008 и СТ РК 988-2007), определившие требования к материалам, палитре цветов, размерам и пропорциям рисунков, областям применения государственных символов. Именно поэтому герб и флаг так сочетаются в цветовой гамме и выглядят как единое художественное произведение.

По сути, щит герба сделан в виде юрты дома, очага казахского народа. Мифические крылатые кони Тулпары изображены здесь как обереги жилища. Можно проследить некоторое сходство Тулпара с единорогом, изображенным на гербе Туркестанского генерал-губернаторства. В этом просматривается преемственность символов. В древней мифологии Тулпар соответствует Пегасу, в мифах же тюркских народов крылатый конь является помощником, советчиком и другом былинных богатырей. Символизм звезды можно отнести к наследию советского герба Казахстана. Изначально в первых эскизах герба было три звезды, что символизировало объединение трех жузов Казахстана. Пятиконечная звезда имеет множество интерпретаций и богатую историю. Одним из образов пятиконечной звезды является человек. С этой точки зрения герб показывает, что все в государстве для человека и он - человек - во главе всего, под защитой Тулпаров у родного очага.

Ввиду того что над созданием герба работала группа архитекторов без привлечения геральдистов и историков, герб не избежал ряда несущественных ошибок. Первой ошибкой является наложение металла на металл. Так, на золотую юрту наложены золотые Тулпары, надпись
«Қазақстан» и звезда. Запрет наложения металла на металл и финифти на финифть является основным догматическим правилом геральдики. История запрета сопряжена с тем, что гербы в древности должны были быть контрастными, а это невозможно достичь, не соблюдая данного правила геральдики. Однако стоит отметить, что история геральдики знает случаи, когда даже столь важные требования умышленно нарушались. Например, Готфридом Бульонским (1060-1100) - одним из предводителей первого крестового похода и основателем Иерусалимского королевства.

Герб нового государства должен был принадлежать и Готфриду. Собравшиеся бароны избрали в качестве герба серебряный щит с золотым крестом, окруженным четырьмя золотыми же крестиками (см. рис. 6). По сохранившейся истории создания этого герба такое отступление от правил геральдики было сделано для того, чтобы отдаленное потомство помнило и чтило причины, по которым ему был дан герб в нарушение правил $[9,52]$. Причина же возникновения такого герба проста. После взятия Иерусалима соратники Готфрида, дабы отметить его заслугу в организации крестового похода, присвоили ему такой нестандартный герб.

Оснований же для нарушения догм геральдики в случае с гербом Республики Казахстан не было. Второй ошибкой в гербе республики является надпись названия государства «Қазақстан». Это своего рода геральдическая тавтология. Герб является названием государства, выраженным в символах. Стоит ли повторять его в письменном виде? Девиз герба должен содержать либо фиксацию доблести предков, либо заповедь потомкам. Название государства не может быть девизом герба.

Символы флага Казахстана самобытны и уникальны. Солнце - символ богатства, плодородия, благополучия. Орел - символ власти и царь-птица. Силуэт казахстанского орла бдительно взирает на землю и при этом набирает высоту. Такие символы показывают свободу государства, его высокие ориентиры и цели. Национальный орнамент, расположенный у древка флага, часто служит шифром, молитвой, оберегом, примером древнего письма, стилизованным представлением растительного и животного миров и т. п. Орнамент на флаге Казахстана скорее можно отнести к арабескам, хотя подобные элементы встречаются и в китайском орнаменте. Вероятнее всего данное изображе- 


\section{Вспомогательные исторические дисциплины}

DOI: $10.7256 / 2222-1972.2015 .5 .17290$

ние символизирует богатый и яркий природный комплекс государства.

Символы Республики Казахстан стали результатом серьезной работы и продемонстрировали основательный подход к этому вопросу руководства государства. Казахстан - единственная страна на постсоветском пространстве, у которой существует не только конституционный закон о символах, но и государственный стандарт, благодаря которому герб и флаг выглядят как единая художественная композиция, сочетающаяся в цветовой гамме и отражающая былинный эпос народа. Дав волю воображению, можно сказать, что единорог с туркестанского герба трансформировался в Тулпара герба современного, а символизм Советского Союза перешел в новый герб посредством звезды и формы герба. В этом и заключается тонкость исполнения герба Казахстана. Он является новым символом, но содержит в себе элементы преемственности. Присутствующие в гербе ошибки скорее являются наследием советской геральдической школы, что показывает интеграционные настроения государства и его неразрывную связь с Россией. Надо отметить, что такие же ошибки присутствуют и в гербе Республики Беларусь. Геральдика Казахстана только зарождается и делает первые, но уверенные шаги. Есть надежда, что в ближайшем будущем в связи с интеграционной политикой Евразийского Союза ошибки символов союзных государств будут исправлены и приведены в единый стандарт.

\section{Библиография:}

1. Валеев Ф. Х., Валеева-Сулейманова Г. Ф. Древнее искусство Татарии. Казань: Татарское книжное издательство, 1987. 204 с.

2. Винклер П. П. Гербы городов, губерний, областей и посадов Российской империи, внесенные в полное собрание законов с 1649 по 1900 год. СПб.: Типография Комелова И. М., 1899. 307 с.

3. Поцелуев В. А. Гербы Союза ССР: из истории разработки. М.: Политиздат, 1987. 166 с.

4. Загоруйко М. В. Символы республики Армения - геополитическое зеркало государства // Политика и общество. 2015. № 1. С. 80-90.

5. Ащеулов А. Т. Конституционное право Республики Казахстан. Алматы: КазГЮА, 2001. 656 с.

6. Загоруйко М. В. Государственные символы Белоруссии: история и значение // Genesis: исторические исследования. 2015. № 1. C. 36-58. DOI: 10.7256/2409-868X.2015.1.13999.

7. О государственных символах Республики Казахстан // Ведомости парламента Республики Казахстан. 1996. № 1. С. 178.

8. государственных символах Республики Казахстан // Казахстанская правда. 5 июня 2007.

9. Лакиер А. Б. Русская геральдика. СПб.: Б. и., 1855. 669 с.

10. Шиповская Л. П., Гемонов А. В. Философская интерпретация геральдических символов Руси периода монголо-татарского ига // Философия и культура. 2013. № 12. C. 1718-1727. DOI: 10.7256/1999-2793.2013.12.10195.

11. Загоруйко М. В. Государственные символы республики Азербайджан: история и значение // Genesis: исторические исследования. 2014. № 5. С. 78-92. DOI: 10.7256/2409-868X.2014.5.13515.

12. Загоруйко М. В. Символы современной Грузии - историческая ретроспектива // Genesis: исторические исследования. 2015. № 3. C. 292-325. DOI: 10.7256/2409-868X.2015.3.14534.

\section{References (transliterated):}

1. Valeev F. Kh., Valeeva-Suleimanova G. F. Drevnee iskusstvo Tatarii. Kazan': Tatarskoe knizhnoe izdatel'stvo, 1987. 204 s.

2. Vinkler P. P. Gerby gorodov, gubernii, oblastei i posadov Rossiiskoi imperii, vnesennye v polnoe sobranie zakonov s 1649 po 1900 god. SPb.: Tipografiya Komelova I. M., 1899. 307 s.

3. Potseluev V. A. Gerby Soyuza SSR: iz istorii razrabotki. M.: Politizdat, 1987. 166 s.

4. Zagoruiko M. V. Simvoly respubliki Armeniya - geopoliticheskoe zerkalo gosudarstva // Politika i obshchestvo. 2015 . № 1. C. 80-90.

5. Ashcheulov A. T. Konstitutsionnoe pravo Respubliki Kazakhstan. Almaty: KazGYuA, 2001. 656 s.

6. Zagoruiko M. V. Gosudarstvennye simvoly Belorussii: istoriya i znachenie // Genesis: istoricheskie issledovaniya. 2015 . № 1. C. 36-58. DOI: 10.7256/2409-868X.2015.1.13999.

7. O gosudarstvennykh simvolakh Respubliki Kazakhstan // Vedomosti parlamenta Respubliki Kazakhstan. 1996. № 1. S. 178.

8. O gosudarstvennykh simvolakh Respubliki Kazakhstan // Kazakhstanskaya pravda. 5 iyunya 2007.

9. Lakier A. B. Russkaya geral'dika. SPb.: B. i., 1855. 669 s.

10. Shipovskaya L. P., Gemonov A. V. Filosofskaya interpretatsiya geral'dicheskikh simvolov Rusi perioda mongolo-tatarskogo iga // Filosofiya i kul'tura. 2013. № 12. C. 1718-1727. DOI: 10.7256/1999-2793.2013.12.10195.

11. Zagoruiko M. V. Gosudarstvennye simvoly respubliki Azerbaidzhan: istoriya i znachenie // Genesis: istoricheskie issledovaniya. 2014. № 5. C. 78-92. DOI: 10.7256/2409-868X.2014.5.13515.

12. Zagoruiko M. V. Simvoly sovremennoi Gruzii - istoricheskaya retrospektiva // Genesis: istoricheskie issledovaniya. 2015 . № 3. C. 292-325. DOI: 10.7256/2409-868X.2015.3.14534. 